\title{
Using Authentic Online Materials for Speaking Class: A Study of Students' Perception about the teaching and learning of English as a Foreign Language
}

\author{
Erlina \\ Sriwijaya University \\ Palembang, Indonesia \\ erlinahamid@yahoo.com
}

\begin{abstract}
This study is intended to find out the students' perception of the use of authentic online learning materials for speaking class in learning English as a foreign language in the Indonesian context. There were 17 students taking speaking class at English Education Study Program of Sriwijaya University, were involved in this study. The result of the questionnaire showed that all of the students $(100 \%)$ agreed that authentic online learning materials are good to be used in speaking class as it makes them become more creative, has high imagination, and enjoy the lesson very much. In addition, the use of authentic online learning materials makes them involved in the real-life activities, such as searching for information based on the topic of discussion, such as arranging a holiday travel. In conclusion, the students perceived that the use of authentic online learning materials is helpful and useful for them in improving their speaking skill.
\end{abstract}

Keywords-authentic online materials, speaking class, foreign language learning

\section{I.INTRODUCTION}

Speaking is one of the skills in learning English as a foreign language. For non-native speakers of English, developing speaking skills is very challenging as it requires the learners to develop many language aspects in order to be able to communicate in the language being learnt. In any foreign language learning, the ability to speak in a language being learnt usually becomes the indicator of a person's success in learning a language. This is because the purpose of learning a foreign language is to be able to use the language as a means of communication. In other words, without the ability to speak the language being learnt, it is difficult to say that someone has already been successful in learning the target language. Unfortunately, many foreign language learners still find that speaking is one of the most difficult skills to learn as it requires the learners to acquire many language aspects which are different from the learners' native language, such as different language pattern, pronunciation, vocabularies, and many others. In addition, it will also be very challenging for foreign language learners when they have to speak in a real situation as they do not have enough opportunities to use English outside the classroom. In Indonesia, English is learnt as a foreign language in which people do not use it as an official language in everyday activities. As a result, English is rarely used and students had low speaking competence. Ref. [1] states that "Consequently, owing to minimal exposure to the target language and contact with native speakers, adult EFL learners, in general, are relatively poor at spoken English, especially regarding fluency, control of idiomatic expression, and understanding of cultural pragmatics." In other words, EFL learners will find it very difficult to develop their speaking competence as they are lack of English exposure.

Teachers might also have problems in developing their students' speaking skills. This might be caused by the following problems. First, it might be related to their own limitation as foreign language users of English. Second, teachers might also find it difficult to develop the students' speaking competence as it is not easy to provide the contextual and meaningful situation for the learners in using the language being learnt. The teaching and learning situation tends to make the students bored as the students are usually asked to do a role play based on some dialogues or repeating some expressions. In other words, the communications tend to be meaningless and the students might easily get bored with such kinds of activities.

Although it might be difficult to develop the students' speaking competence in using English, effort must be done to help the students acquire this important skill. Some language learning theory emphasizes the importance of language as a means of communication which mainly functions as interactional and transactional [1]. Both ways of communication are important as the first focus on maintaining a social relationship while the second one is intended to "convey information and ideas" [1]. In other words, in order for communication to occur, people need to get involved in having interaction with other people or having a purpose in mind about what they are going to convey or deliver as "communication derives essentially from interaction" [1]. Therefore, as an effort to help the students develop their English-speaking competence, providing opportunities for the students to get involved in meaningful communication activities is one of the possible ways. Ref. [1] suggests that "using leaner-learner interaction is the key to teaching language for communication." In other words, encouraging interaction activities between and among the students in language teaching is beneficial for promoting communication. Therefore, language teaching and learning should be designed on the basis of communicative activities which encourage interaction between or among the students.

The development of science and technology, such as computer and internet, has brought a lot of benefits in any field, 
including in the area of language teaching and learning. Ref. [2] state that "computers connected to the internet are, therefore, regarded as tools or "resources to help [students] develop higher order thinking, creativity, research skills, and so on", thus promoting social interaction and learning". In other words, computer and internet could be used as a teaching and learning media as they could be used to facilitate the students' learning. As a resource, the internet is also an effective media which is used "as a way to bring authentic materials into the classroom" [3]. According to [4], authentic materials refer to materials which involve language naturally occurring as communication in native-speaker contexts of use, or rather those selected texts where standard English is the norm." The example of authentic materials are real newspaper reports, for example, real magazine articles, real advertisements, cooking recipes, horoscope, etc [4]. The use of authentic materials has found to bring several positive impacts on language learning. First, they provide opportunities for the language learners to promote real life and communicative use of the language being learnt. Ref. [5] state that "In order for students to learn to communicate effectively in a foreign language, they must experience the language as it is used for real communication by native speakers." In addition, the use of authentic materials can help the students to increase their learning ability. Ref. [6] states that "authentic communicative situations in conjunction with the cultural artifacts and metalinguistic clues offered by the context can promote active learning". Furthermore, the use of authentic materials also brought benefit for the students' motivation in language learning. Based on the study on the use of authentic materials conducted by [6], it was found that "on-task behavior and observed motivation increased significantly when authentic materials were used..." This means integrating real-life communicative situations as well as real life or authentic materials is necessary in order to promote communicative and meaningful language use among the language learners.

Nowadays, people use internet for many different purposes, such as searching for information, chatting, entertaining, or doing some online business. People get connected to the internet almost every day, whenever and wherever they are. In other words, the internet has become part of most people's life. In relation to language teaching and learning, the use of the internet is very useful not only as resources but also in promoting reallife communicative situation activities. For example, when the students are assigned to plan their holiday travel to certain places, they must search some information from the internet related to their needs, such as where they are going to go, how they are going to go there, where they are going to stay, activities they are going to do, the price for the transportation and the accommodation, the food that they can eat, and many others. All of the information is available on the internet and the students could discuss their choices with their friends and enjoy the activities because the information is real and full of pictures. In other words, the use of online materials is expected to give a valuable impact on the students' learning as it has many benefits. First, it is close to the students' world as they love to do online activities in their everyday life. Second, it provides students with a lot of real information which help them to develop a meaningful and contextual situation for their speaking performance. In short, online learning activities provide opportunities for the students to develop their English learning, especially speaking as they engage in online learning activities and involve in real life communicative situation which encourage them to speak in a purposeful, meaningful, and communicative way.

Therefore, this study is intended to find out the students' perception on the use of authentic online learning materials in speaking class as an effort to improve the students' speaking competence in using English as a means of communication.

\section{METHODS}

The participants of this study were 17 students of English and Education Study Program, Faculty of Teacher Training and Education, Sriwijaya University, who were taking speaking one course. Speaking one is one of the subjects which focuses on developing the students' speaking competence. The instrument used in this study was a questionnaire regarding the students' perception of the use of online materials in speaking class. It was an open question questionnaire with three questions: (1) What do you think about the use of online learning materials for speaking class? (2) Does it influence your motivation to improve your speaking?, and (3) Does it make you easier to develop your speaking? The questionnaire was given to the students at the end of the semester after they finish their speaking one course. The data were then qualitatively analyzed; some of the data were quantified using percentage. Firstly, all of the data were categorized based on some major themes of the findings, coded, and analyzed. The categorization and coding of the data helped the researcher to see the trend of the students' responses and find the relevant data which were relevant to the research questions. Finally, the selected data were then interpreted analytically as to reveal the students' perception toward the use of online learning materials in speaking class.

\section{RESULTS AND DISCUSSIONS}

The students' responses on the questionnaire given to them at the end of speaking one course were discussed in three sections. For the first question "What do you think about the use of online learning materials for speaking class?" All of the sample $(100 \%)$ agreed on the positive contribution of online learning materials in speaking class. The responses can be classified into two categories. First, using online learning materials were perceived as great, useful, effective, innovative, enjoyable, and unique way of learning. Second, online learning materials were also perceived as great learning resources.

As a great way of learning, the use of internet in speaking class promotes interactive and real-life activities. The students involved in problem-based learning activities in which they were asked to solve some problems, such as planning a holiday travel. This task required the students to discuss with their group's anything related to their plan, such as where they are going to go, how they are going to go there, where they are going to stay, what they are going to do, the budget they have to provide, and many others. The students were asked to search the information they needed from the internet. They need to discuss their choices with their groups and present the results of their discussion to 
the class. The use of internet in speaking class also promotes other learning outcomes, such as helping students to become independent learners. As the internet has many things to offer, students are motivated to search more and more information to suit their needs. This will obviously engage them in a deep learning and become more aware of relevant and not relevant information related to the topic being discussed. In other words, the students became active and their brain functions optimally. They also learnt how to do some online transaction, such as booking a ticket online and many others. This is very important as the world system is getting more online and students must have those kinds of skills for their future life. In conclusion, the use of internet had facilitated the students' learning either in learning speaking or in their life skill development. The following is the student's response to the use of online learning materials in speaking class.

"I think it's very useful, effective, and innovative. I really like this activity because it makes me easy to speak and improve the conversation. I really enjoy it very much because we can easily get new information, so we can improve our knowledge. I'm also more confident to speak. It makes us be more creative to develop the plot of the conversation. This kind of activity should be improved more as I believe the students will be more enjoyable in speaking English. This activity never makes me feel bored..."

Internet had also become a very good source for the students to find all information they needed. It was enjoyable since the students could use their imagination to make the plan as the information provided on the internet was varied and unlimited. One of the groups was so proud to present that they were going to go with Emirates, which is one of the most expensive and luxurious airlines in the world. They were so excited to show the details and all the services provided by the airplane and hope that someday, it becomes a reality. All students also chose many interesting places for their traveling destination around the world. The students really enjoyed the activities as if they involved in a real-life discussion because all of the information provided on the internet were real, fascinated, and beyond their imagination. In addition, the students also stated that the information available on the internet was up-to-date and more interesting than books. In other words, the use of online learning materials helped the students to engage in real life activities. Therefore, it becomes a unique way of learning for the students.

"The use of online learning for speaking class, I think that is good, we can find another unpredictable and advantageous information. For example, when we tried to find information about the flight, we found very detail information about the services, the price, and the facilities. Moreover, we knew about which one the best flight, the cheaper flight, and the expensive one."

For the second question, "Does it influence your motivation to improve your speaking?" Only two students (11.7\%) perceive that the use of online learning materials did not really influence their motivation to improve speaking since motivation should come from inside and they need experts to help them improve their speaking. However, most of the students (88.3\%) perceive that the use of online learning materials influences their motivation in speaking. It boosted their motivation in one way or another as doing online activities is actually the students' hobby. Thus, they enjoyed the activities and found it interesting to do their hobby as part of the learning process. It motivated them to speak because online activities provide them with a lot of information related to the topic being discussed. It obviously helped them to speak longer and cannot wait to share what they got from the internet related to the topic being discussed.

"There are many techniques in teaching and learning. And also in speaking class, but in my speaking class with ma'am Erlina, we have online learning material for speaking class. The method of online learning material in my speaking class is we have to find the material about the certain theme from the lecturer on the internet, then they make conversation and present it in front of the class. I actually love this method, because it makes me and my friends more update on the latest thing and more creative in improving our idea of speaking. It's also the fun and great way to speaking class, I think. Of course, It automatically influences my motivation to improve my speaking. It pushes me to update and to search the hottest thing. It makes me speaking in pleasure. It also makes me easier to develop my speaking, because I speak with pleasure. As a prospective teacher, I hope that someday I'll also implement this method in my teaching. So my pupils are going to speaking fluently and pleasant. Aameen."

For the third question, "Does it make you more easily develop your speaking ability?" one student $(0.06 \%)$ stated that the use of online learning materials did help her to develop her speaking skill but only a little. Other students (94\%) agreed that online learning materials help them to develop their speaking skills. Most students found that the use of online learning materials helps them to develop their speaking in many ways. Having an easy access to a lot of materials is among the reasons why the students find it helpful to use online learning materials for speaking class. The students also found it easier to improve their speaking since the materials they found on the internet were more interesting, varied, and up-to-date compared to the materials from the books. This eventually increases their interest and makes them speak with pleasure as they have a lot of things to share from what they searched from the internet. In other words, the use of online learning materials is useful in helping the students' develop their speaking ability.

"Of course, it does. Online activity makes easier to make improvisation in speaking. It's not boring. It's enjoyable. Compare to read the speaking book, online activity is pretty much better than it. First, the material in the book is fewer than online activity. In online we have many topics to be made as conversation. However, through speaking book, we can learn a new expression in speaking. While in online activity we only speak or do conversation base on our expression. Second, online activity makes us enjoy speaking English. That's important because when we enjoy speaking 
English, we will be more confident and it will make us want to speak English more and more. Last but not least, online activity gives us new knowledge. However, I think our wifi should be improved in order to make this sort of activity easier to be done (that's one of the reasons why I rate this activity 4.5 stars). So, we can use video as our material to have a conversation."

\section{CONCLUSIONS AND SUGGESTIONS}

Providing conducive learning environment is very important as it provides more opportunities for the students to develop their potential. In order to develop speaking competence, students need to have learning environment which can promote their potential in using the language as a means of communication. The use of online learning materials in speaking class has been perceived by the students as great learning resources as well as a unique way of learning. Students found it interesting to do online activities during the speaking class because it creates fun and enjoyable learning situation as doing online activities is part of the students' daily hobby. It also involved the students in real life activities as the lessons were developed on the basis of dailybased-life themes in which the students need to solve some problems, such as planning a holiday travel, doing online shopping, and many others. In other words, students perceived positive contribution on the use of online learning activities in speaking class and found it useful in increasing their motivation as well as their speaking competence.

Regarding the importance of creating a conducive learning environment in promoting the students' communication skills, the use of online learning activities can be one of the alternatives in developing the students' speaking competence. Based on the results of the study it was found that the use of online learning materials helped the students in developing their speaking competence. The students enjoyed the lesson and found it easier to develop their speaking skill as the internet provided a great variety of resources that they can use to discuss the topic. Therefore, it is suggested that more online learning activities are used in the teaching and learning process especially in the teaching and learning of English as a foreign language.

\section{REFERENCES}

[1] Shumin, K. (2002). Factors to consider: Developing EFL students' speaking abilities in Methodology in Language Teaching: An Anthology of Current Practice. Retrieved from http://books .google.co.id/books

[2] Thousny, S. \& Bradley, L. (2011). Second Language Teaching and Learning with Technology: Views of emergent researchers. Researchpublishing.net.

[3] Zhao, Y. (2003). Recent development in technology and language learning: A literature review and meta-analysis in CALICO Journal, 21(1), pp. 7-27.

[4] Kilickaya, F. (2004). Authentic materials and cultural content in EFL classroom on the Internet in Internet TESL Journal. Retrieved from itsel.org.

[5] Rogers, C.V., \& Meddley, F. W. (1988). Language with a purpose: Using authentic materials in the foreign language culture, 21(5), pp. 467-478.
[6] Palalas, A. (2011). Mobile-Assisted Language Learning: Designing for your students. Dublin: Research-publishing.net.

[7] Peacock, M. (1997). The effect of authentic materials on the motivation of EFL learners in ELT Journal, 51(2), pp. 144-156. 